\title{
NOSTALGIC SENTIMENT AND CULTURAL AND CREATIVE INDUSTRIES IN REGIONAL DEVELOPMENT: A SLOVAK CASE STUDY
}

\author{
Kamila Borsekován ${ }^{1}$, David Cole², Katarína Petríkována , Anna Vañová ${ }^{3}$ \\ ${ }^{1}$ Institute of Economic Sciences, Faculty of Economics, University of Matej Bel, Banská Bystrica, Slovakia \\ ${ }^{2}$ Department of Language Communication in Business, Faculty of Economics, University of Matej Bel, \\ Banská Bystrica, Slovakia \\ ${ }^{3}$ Department of Public Economics and Regional Development, Faculty of Economics, University of Matej Bel, \\ Banská Bystrica, Slovakia
}

Manuscript received: October 2, 2014

Revised version: April 1, 2015

Borseková K, Cole D., Petríková K., VañovÁ A., 2015. Nostalgic sentiment and cultural and creative industries in regional development: a Slovak case study. Quaestiones Geographicae 34(2), Bogucki Wydawnictwo Naukowe, Poznań, pp. 53-63, 3 figs, 3 tables. DOI 10.1515/quageo-2015-0015, ISSN 0137-477X.

AвSTRACT: In Slovakia, there are three unique, historical mining towns, Banská Bystrica, Banská Štiavnica and Kremni$\mathrm{ca}$, that have been successfully turned into creative cultural centres. The historical and cultural values of those towns have stood the test of time and become a magnet for a new and creative class of people looking to escape the brutality of high modernity (modern urban centres) and find a source of inspiration based on historical nostalgic sentimentalism - the basis for a new creative and cultural industry for rural areas. The main objective of this paper is to analyse the cultural and creative industries of these three unique historical mining centres with an eye to replicating their knowledge in other communities in economic stress. The paper will first explore concepts relating to cultural and creative industries with an eye towards nostalgic sentimentalism that is an important antithesis to high modernity, and even post-modernity. The second part will analyse the cultural and creative industries of the three centres based on primary data collected from several research projects in this area. The final part will provide some recommendations for the facilitation of creative and cultural enterprises in regional redevelopment. It also contains policy recommendations for the self-government of the region for a more effective and rational exploitation of the existing potential hiding in plain view.

KEY WORDS: cultural and creative industries, modernity, nostalgia, rural redevelopment

Address of the corresponding author: Kamila Borseková, Institute of Economic Sciences, Faculty of Economics, University of Matej Bel, Cesta na amfiteáter 1, 97401 Banská Bystrica, Slovakia; e-mail: kamila.borsekova@umb.sk

\section{Introduction}

The development of the creative and cultural sector, which is based on internal resources of an area, can be an important engine of territorial development. It can ensure a strong, unique, and sustainable competitive advantage on which it is possible to build territorial development. The factors that help to create and build such a competitive advantage are human capital, tangible and intangible potential, history, and unique traditions. These advantages can only be exploited with proper financial resources willingly provided in expectation of a sufficient return on investment.

Several researches (Borseková et al. 2012, Pompurová 2011) have shown that Slovakia and several of its localities have the potential to become unique tourist destinations and achieve territorial development based on a more efficient 
use of cultural and creative industries. This was confirmed by one of the world's leading tourist guides, Lonely Planet, that ranked Slovakia in the top 10 countries for travelling in the year 2013. Another very important advantage is that the second biggest city in Slovakia, Košice, was the European Capital of Culture in 2013 together with the French city of Marseille. These two aspects help Slovakia to promote itself and to attract more domestic and foreign tourists. Although the potential has been identified, the truth is that it is still not being fully used and needs to be unlocked.

The government all too often treats all areas of the country equally with rules and regulations designed for metropolitan centres without really considering the needs of some of the less-favoured areas. Therefore, there is now a wholesale abandonment of entire regions in Slovakia. Small towns and their idyllic settings are looked upon nostalgically, but are forgotten in the grand scheme of economic progress. They are still seen only as settlements used to feed a local industry rooted in some way to the primary or secondary sector of the economy (agriculture/mining and manufacturing). These sectors are not seen as areas of creativity or growth and, thus, small towns are an afterthought. It is as if small communities of Europe would somehow always exist, and somehow and in some way, someone would want to live there.

All individuals in society look to find the best alternative for themselves, and this desire can be expressed in terms of both material attainment and societal status. Thus, individuals try to complete their 'life story' by choosing options that will leave them with a respectable legacy. This narrative extends beyond the self to include the family with expectations from parents, spouse, and present and future children.

The 'life narrative' that individuals seek is based on two opposing concepts - modernity and nostalgia. It can be said that a metropolitan area is well rooted in modernity with the constancy of the new, while rural areas ${ }^{1}$ are considered bastions of nostalgia. The importance of nostal-

In this article, the term 'rural areas' denotes all small cities, towns, and villages that lie outside large metropolitan areas. With only two cities, Bratislava and Košice, that can truly be considered metropolitan, Slovakia is mostly rural. gia is largely overlooked in the scheme of economic development, and its economic potential is ignored as a possibility for economic growth in rural areas. This leads to the problem where modernity dictates rules and conditions for a country as a whole, and nostalgic sentiment, with only a few exceptions, is not allowed to flourish. These nostalgic sentiments can be considered a major element of cultural and creative industries, especially for small cities, towns, or villages. In sociological terms, it can be described as a counter-force to modernity based on historical nostalgia.

Before any discussion about rural development can begin, the importance of nostalgic sentiment in regional development needs to be understood. Therefore, this paper will first explore the principles of nostalgia vs. modernity from the perspective of creative and cultural industries, with an eye towards unlocking its competitive advantage. The second part will analyse three different historical centres as case studies for creative and cultural redevelopment. The final part will provide important recommendations for the facilitation of creative and cultural enterprises and individuals in regional redevelopment.

The paper presents the results of the project VEGA V-14-101-04 Creative industries delivering crucial intangibles to the public sector in terms of innovation and smart growth.

\section{Nostalgia as a competitive advantage and its relationship to cultural and creative industries}

\section{Nostalgia vs. modernity in living choices}

In a pure capitalist concept, neoclassic theory would dictate that as an area becomes too expensive or too inconvenient to live in, people would migrate to more inexpensive locations looking for better opportunities and a different lifestyle. In spatial terms, this rebalancing exists outside metropolitan areas, where cheaper suburbs and even cheaper exurbs spring up to meet demands for an appropriate living space within a metropolitan area. An even more profound cost advantage would be to move further afield, to less populated rural areas outside the influence of the metropolitan area. The cost advantage of the ru- 


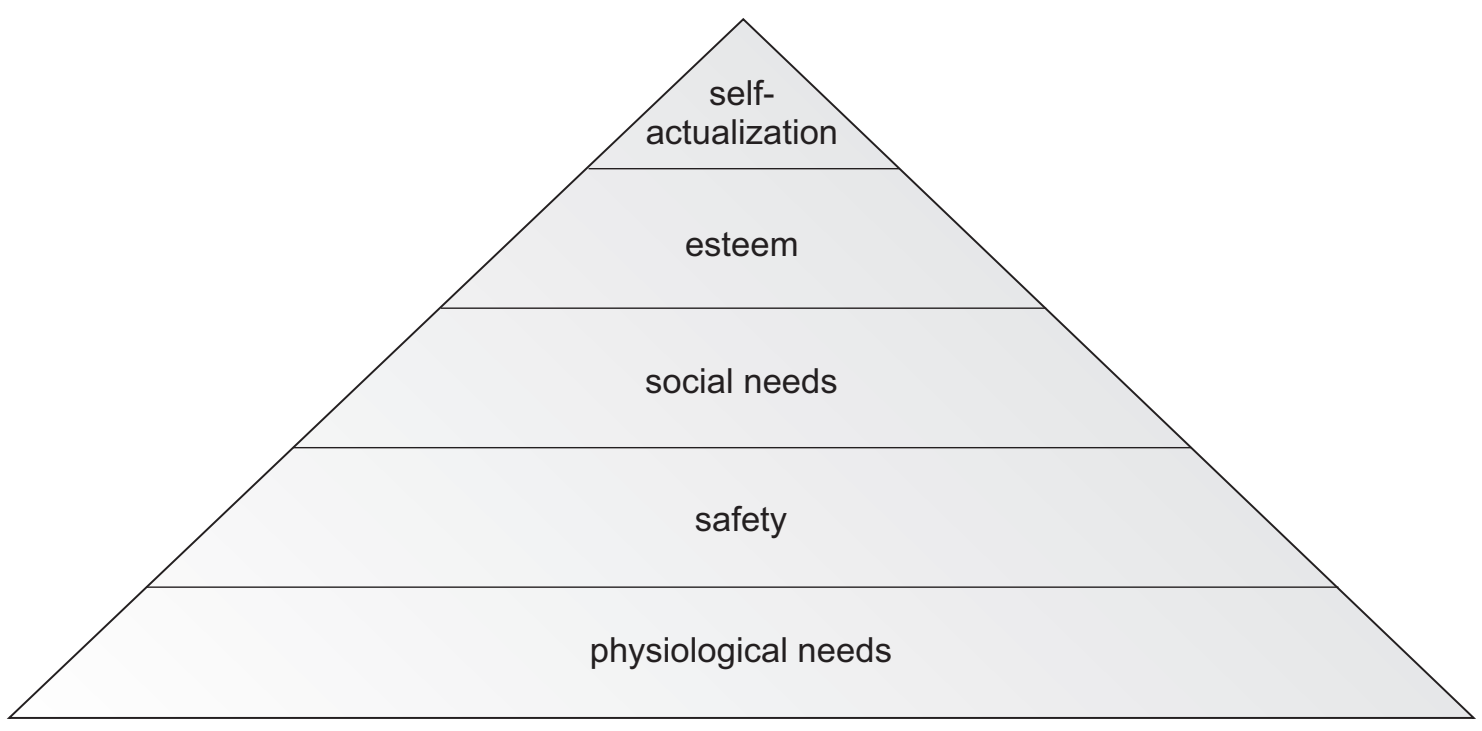

Fig. 1. Maslow's hierarchy of needs.

Source: own elaboration based on Maslow.

ral area has to be viewed both from an economic and a social point of view. Economists tend to focus on monetary measurements but, important though this is, it is not always the most endearing measurement of who we are as individuals. Man is a social creative animal, not a monetary one.

Large metropolitan areas provide many outlets and a variety of economic opportunities which help to reinforce even more economic activity. For all individuals, the most important basic needs must be met first. These needs are best known as arranged by Abraham Maslow in a hierarchy of needs (Fig. 1). The abundance of economic activities provided by an agglomerated area provides for the basic physiological needs (food, water, sleep, etc.), the safety needs of a physical shelter and psychological security, and the social needs of love, friendship, and social interaction. Once these needs are met, the higher needs of esteem (respect from other people) and self-actualisation (the realisation of our full potential) are sought, but could be limited by the cost of their fulfilment. These needs are as much rooted in the past (nostalgia) as they are part of future aspirations (modernity).

Neoclassic theory suggests that man is forward-looking and is thus mainly concerned with modernity. This view disregards the past, overlooking the historical markers that give us our identity. This historical desire could be described as a state of nostalgia - a sentimentality for a past time or place associated with happiness. In terms of demographic spatial relationships, a small town is rooted in nostalgia and urban centres in modernity. Although this statement may seem superficial and rudimentary, there are historical references to the problem of urban modernity by philosophers, artists, and sociologists. Charles Baudelaire described the modern city as a poet's imperfect home. Svetlana Boym (2002) describes nostalgic sociologists (Weber, Simmel, Lukacs) not as being anti-modern, but rather critical of the effects of modernisation, much of which is rooted in the urban setting. The discussion of the urban vs. the rural must therefore be preceded with a description of nostalgia vs. modernity, especially in the post-communist countries of Europe.

Historically, nostalgia was viewed as a disease more akin to homesickness - nostalgia is coined from the Greek words nostos (a return home) and algos (pain) ${ }^{2}$. Modern-day conceptions of nostalgia, however, see the word in terms that are more positive. Batcho (2013) states that even though nostalgia can be triggered by negative stressors in the environment, it can result in successful development of methods for coping, planning and implementing strategies for a more positive outcome. Zhou et al. (2008) found that nostalgia led to a sense of social support and connections and a way to cope with loneliness. In a study by Vess et al. (2012), subjects who thought of nostalgic memories had better coping mechanisms than those whose thoughts were of exciting future ex-

2 http://www.etymonline.com/index.php?term=nostalgia. Accessed on 31 Dec. 2014. 
periences. Furthermore, the future-thinking subjects showed signs of selfishness and self-centred attributes. Routledge et al. $(2011,2012)$ claim that nostalgic thoughts could help to create a meaning and coping mechanisms out of existential threats. Therefore, it is felt that nostalgia has a place in modern society.

Central Europe endured a long period under a command economy, which was profoundly ideological in its approach to modernity. This adherence can be called high modernity and can be described as strong confidence in scientific and technological progress, a reliance on experts (scientists, engineers, bureaucrats, etc.), an attempt to master nature to meet human needs, spatial ordering (urban planning, housing, and transport), and disregard for the historical, geographical and social context in development (Scott 1998). This ideology of modernity materialised in the real world in the form of brutality seen in concrete tower blocks, utilitarian design, and general dullgrey tedium. As this brutality was more concentrated in urban areas, rural areas still retain icons more rooted in forms from a nostalgic past. Even the non-socialist western countries had a flirtation with high modernity, as the post-war period flirted with the Malthusian prospect of a future of an ever-growing population and severe strains on resources.

The post-cold-war period saw a change in central European countries from high modernity to a unique form of post-modernity. This new form of modernism can be described as a hyper-technological version of modernism (Appignanesi et al. 1995: 126). Their unique position of having to catch up with western and even eastern countries (Japan, Korea) led them to a more distinct worship of technology-led post-modernism. In terms of geographical development, urban centres become the launching points for modernism in a country at the expense of their rural counterpart.

Anthony Giddens (1990) opposed this attitude towards post-modernism, arguing that "social practices are constantly examined and reformed in the light of incoming information about those very practices, thus constitutively altering their character". He also proposed an alternative to post-modernism suggesting that we lived in an era of disembeddedness of time and space, with blurred lines separating the local from the global and the past from the future. Individuals no longer have to be in the physical presence of each other in order to interact - what Giddens refers to as time-space distanciation. This suggests an existing paradox in mass urbanisation: if technology has led to the disembeddedness of the physical necessity to be in close proximity to each other, then why does the urbanised metropolitan area continue to grow even when it becomes economically and spiritually repressive? Moreover, what should be done with its smaller, more rural counterpart?

Nostalgia has an advantage over modernity in that historical markers are forever open to reinterpretation. As individuals engage in nostalgic sentiment, a choice-supportive bias will find positive sides in past experiences while minimising negative ones. This means that an investor in a rural area looks for a nostalgic connection and is, thus, willing to overlook negative aspects of his choice, even when there is little economic advantage.

In sum, it can be said that nostalgic sentiment is in short supply in the metropolitan centre but can be found in abundance in the rural region. It is our contention that this nostalgic sentiment is a big competitive advantage for rural development.

\section{Nostalgia as a competitive advantage for rural areas}

With only two major metropolitan centres, Bratislava and Košice, Slovakia has escaped much of the forces of socialist high modernity that was so destructive to the historical heritage. This presents a competitive advantage based on the abundance of nostalgic elements found throughout the country. Authors (Martin 2002, 2005; Kitson et al. 2004) insist that a regional competitive advantage has to include not only "hard" productivity but also "softer" dimensions of the social economy. When applying the softer dimensions to regional development, it is a specific feature, an attraction or uniqueness which has a certain value for customers/ consumers in a region (residents, tourists, business people, and investors), and these customers prefer this value over that offered by competing regions (Borseková, Vaňová 2011).

There are several theoretical approaches to a competitive advantage. Many economists agree on two basic ones: a market-based approach and 
a resource-based one. When applying them to rural regional advantages, five competitive features can be determined:

- a competitive advantage of endogenous resources such as "hard" resources (mineral extraction, manufacturing) and "soft" ones (landscape, historical, cultural heritage),

- a competitive advantage of uniqueness that can only be found in a given local area,

- a competitive advantage of low costs, as supply and labour costs have an advantage over other regions,

- a competitive advantage of market-oriented resources such as unique branding, and

- a competitive advantage of exogenous resources such as the presence of foreign investors and foreign influences in the local economy.

The abundance of icons and elements of historical significance in the Slovak regions falls under each of the above advantages in a unique way that is hard to match by potential competitors. The abundance of historical and iconic structures in a beautiful natural setting must be considered an endogenous resource. Their historical and regional features cannot be duplicated in another area as authenticity would be lost. These nostalgia icons can be obtained at extremely low prices, and labour prices help to reconstruct and repurpose them in an inexpensive way. As a member of the EU, and one that has adopted the euro as its currency, Slovakia is relatively open to foreign investment. Each area offers a unique brand identity, especially historical identity (examples include regional identities such as Hont, Gemer, Tokaj, Šariš, etc.). Advantages of historical/ nostalgic icons present a unique opportunity for the country; unfortunately, many of them are in a desperate state of disrepair.

\section{Impact of cultural and creative industries on territorial development from a theoretical point of view}

Modern rural development can be approached from a nostalgic point of view of the cultural heritage. This nostalgia, a reaction to post-modernism, is a part of cultural and creative industries which have to be defined further.

There are several definitions of cultural industries. They produce and distribute cultural goods or services "which, at the time they are considered as a specific attribute, use or purpose, embody or convey cultural expressions, irrespective of the commercial value they may have" (UNESCO 2005). The cultural industry, directly or indirectly, represents an important part of the wealth of society, and can include publishing, music, cinema, and multimedia. Crafts and design are also included in this industry, and this concept has been widened to incorporate certain creative activities, such as architecture and various artistic categories (Poussin, Schischlik 2005). We contend that architecture, especially historic architecture, is a prized commodity for creative and cultural industries. If this were not true, then this industry would be just as content to be located in a non-descript corrugated metal building located in an industrial zone. This environment (a rebellion to modernity) becomes a main driver for movement to a rural area.

There are also several definitions of creative industries. We are, however, inclined to the 1998 definition given by the Department for Culture, Media and Sport (DCMS) in the United Kingdom, which defines them as "those industries which have their origin in individual creativity, skill, and talent, and which have a potential for wealth and job creation through the generation and exploitation of intellectual property".

Power (2011) argues that despite differences, there is a considerable overlap with industries that are involved in creative and cultural outputs and those concerned with creative inputs and processes. The present authors use the terms interchangeably, but also take them as conceptually linked and similar. Indeed, policies and academic debates find it convenient to use the label 'creative and cultural industries'. "This set of enterprises includes all market-oriented companies financed through the market, liable to pay turnover taxes or simply all those that want to earn money with art, culture and creativity" (Söndermann et al. 2009: 20).

Cultural and creative industries which flourish at the local and regional levels are in a strategic position to link creativity and innovation. They can help to boost local economies, stimulate new activities, create new and sustainable jobs, have important spill-over effects on other industries, and enhance the attractiveness of regions and cities. Creative industries are therefore 
catalysts of structural change in many industrial zones and rural areas with the potential to revive their economies and contribute to a change in a region's public image. They should be integrated into regional development strategies in order to ensure an effective partnership between civil society, businesses and public authorities at the regional, national, and European levels (Communication from the Commission to the European Parliament, the Council, the European Economic and Social Committee and the Committee of the Regions, 2010). Without direct involvement and participation of all these subjects, it is not possible to talk about the sustainable and market-oriented development of an area (Vaňová et al. 2010).

\section{A case study of cultural and creative industries in Slovakia - the historical mining centres of Banská Bystrica, Banská Štiavnica, and Kremnica}

Interesting architectural objects from previous generations become icons of nostalgia. Creative industries help to transform or rather 'repurpose' these objects, while the cultural industry restores monuments that memorialise our past existence. Both are major attractions for the tourist sector, so a study of this sector provides a measure of their overall success in rural redevelopment. It has to be said that Slovakia
Table 1. Cultural and historical heritage in the Banská Bystrica region.

\begin{tabular}{|lrc|}
\hline \multicolumn{3}{c}{ Cultural monuments in districts } \\
Banská Bystrica & 537 & $20.29 \%$ \\
Banská Štiavnica & 395 & $14.93 \%$ \\
Žiar nad Hronom & 276 & $10.43 \%$ \\
Rimavská Sobota & 230 & $8.69 \%$ \\
Krupina & 214 & $8.09 \%$ \\
Brezno & 197 & $7.45 \%$ \\
Levice & 183 & $6.92 \%$ \\
Revúca & 167 & $6.31 \%$ \\
Zvolen & 159 & $6.01 \%$ \\
Vel'ký Krtíšs & 110 & $4.16 \%$ \\
Žarnovica & 102 & $3.85 \%$ \\
Detva & 49 & $1.85 \%$ \\
Poltár & 27 & $1.02 \%$ \\
Total sum of monuments & 2,646 & $100.00 \%$ \\
\hline
\end{tabular}

Source: data from the Monuments Board of the Slovak Republic, 2014.

as a tourist market will never become a tourist Mecca like Paris, London or Prague. Just like the hajj pilgrimage for devotees of Islam, many people aspire to visit certain locations throughout the world in order to be able to say "I've been there", "I've done that" (Cole, Mazureková 2014). Thus, the tourist potential of the Banská Bystrica region of Slovakia caters to a niche experience of the more intrepid traveller. By itself, tourism cannot be the sole panacea for the economic ills of a region, but it exists in symbiosis with creative and cultural industries.

This section examines three unique, historic mining towns - Banská Bystrica, Banská Štiavni-

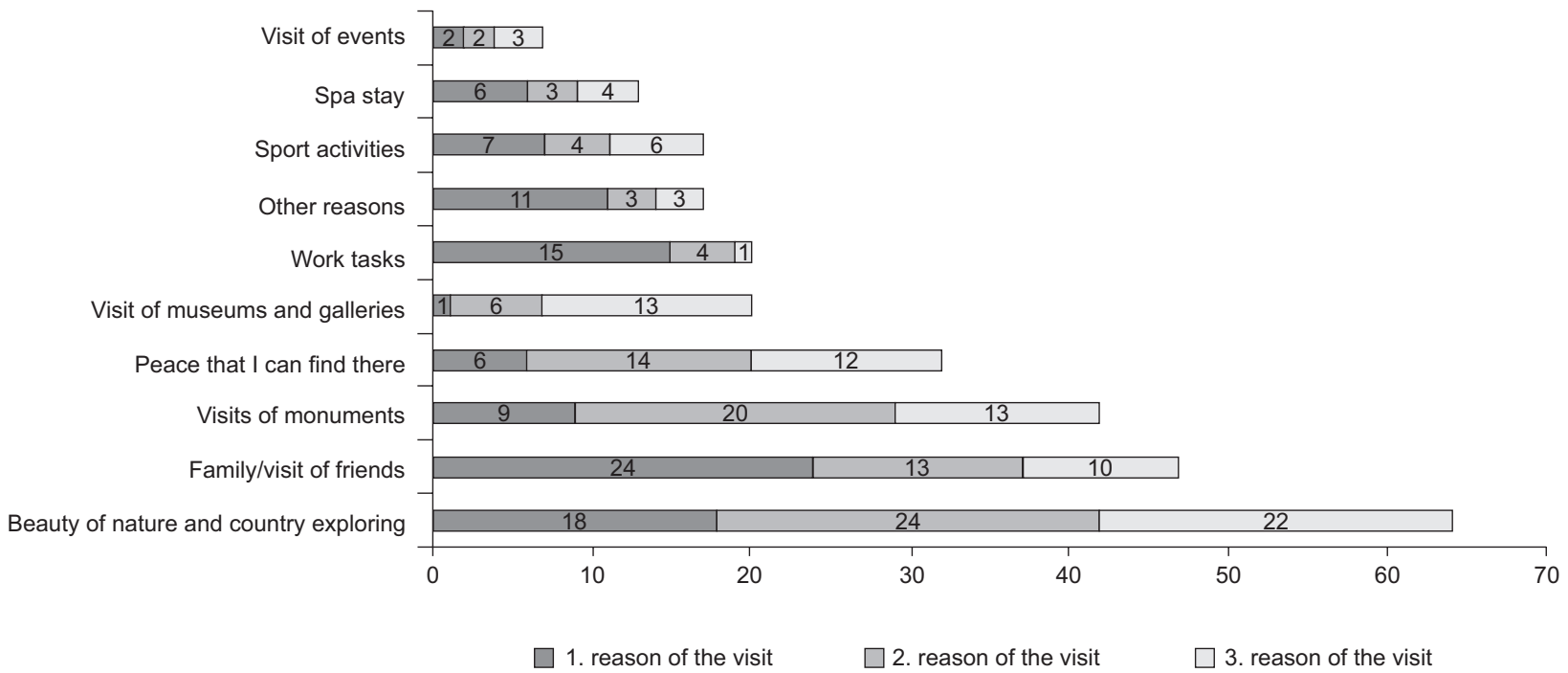

Fig. 2. Purpose of tourist visits in the Banská Bystrica region in 2013. Source: own research. 
Table 2. Number of visitors in tourist accommodation and its change, 2008-2012.

\begin{tabular}{|c|c|c|c|c|c|c|c|c|c|}
\hline & \multicolumn{9}{|c|}{ Number of visitors in tourist accommodation } \\
& 2008 & 2009 & $2009 / 2008$ & 2010 & $2010 / 2009$ & 2011 & $2011 / 2010$ & 2012 & $2012 / 2011$ \\
\hline $\begin{array}{c}\text { Žiar nad } \\
\text { Hronom }\end{array}$ & 54.395 & 42.308 & $-22.22 \%$ & 45470 & $7.47 \%$ & 47.108 & $3.60 \%$ & 46.705 & $-0.86 \%$ \\
\hline $\begin{array}{c}\text { Banská } \\
\text { Bystrica }\end{array}$ & 96.514 & 78.613 & $-18.55 \%$ & 8.168 & $3.25 \%$ & 85.175 & $4.94 \%$ & 84.344 & $-0.98 \%$ \\
\hline $\begin{array}{c}\text { Banská } \\
\text { Štiavnica }\end{array}$ & 18.296 & 14653 & $-19.91 \%$ & 17.304 & $18.09 \%$ & 19.041 & $10.04 \%$ & 21.960 & $15.33 \%$ \\
\hline
\end{tabular}

Source: Slovak Statistical Office data, 2014.

ca and Kremnica - in the Banská Bystrica region. It is located in central Slovakia and is the largest of its eight regions. Its terrain varies from rugged mountains, through a range of hills and valleys, to expansive farmland in the south. The seat of the region is the city of Banská Bystrica. The region includes three national parks: the Low Tatras, Muránska planina and Slovak Paradise, and five protected natural areas (including the Pol'ana UNESCO biosphere reserve).

Macroeconomic indicators from the Slovak Statistical Office (2014) paint a rather dismal picture of the area as its economic performance is quite low. The unemployment rate stands at $20.81 \%$ (for Slovakia as a whole, $14.44 \%$ ); the average nominal wage is $€ 675$ (Slovakia - €805); the regional GDP in PPS per inhabitant - €13,200 (Slovakia - €17,900), and population density 69.8 people $/ \mathrm{km}^{2}$ (Slovakia - 110.2 people $/ \mathrm{km}^{2}$ ).

Our research, however, found the region to have a strong competitive advantage over other regions with its many tangible and intangible cultural heritage values. UNESCO defines tangible assets in terms of the built environment (buildings, townscapes, archaeological remains), while intangible ones are the living expressions of culture inherited from our ancestors (music, crafts, traditions, folklore, etc.). Out of the 2,646 cultural monuments in this region, almost half are in three regions: Banská Bystrica, Banská Štiavnica, and Žiar nad Hronom (the district that contains Kremnica; see Table 1).

These areas are also sites of significant annual events that can be considered their intangible assets. The biggest attraction for each of the three cities is listed below:

1. Banská Bystrica: Radvanský jarmok (Radvaň fair), a traditional cultural event with the market of craft and home-made products organised in Banská Bystrica each September; this year it will celebrate its 358th anniversary.
2. Banská Štiavnica: Salamandar is a procession lasting two hours that presents to visitors the entire history of Banská Štiavnica, starting with the legend about the discovery of gold and silver up to the present day. A herdsman, the discoverer of gold and silver ore, is always at the head of the Salamander procession of costumed characters, musicians, and variety entertainers. This event is held each September.

3. Kremnica: Gagy, a European festival of humour and satire. It is a unique international event with the presentation of cultivated humour, independent satire, and lively fun, held annually at the end of August since 1981.

The diversity of historical and cultural tangible and intangible monuments in the Banská Bystrica region is a suitable starting position for further development of its cultural industry and cultural tourism. However, the number of visitors is highly variable (see Table 2), while the number of tourist overnight stays has permanently declined ${ }^{3}$ and their stay in the region has been shortened during the last years. Banská Štiavnica, however, shows signs of success as it has become more established in tourism and other creative activities.

This research was followed up by a questionnaire survey of 100 Slovak tourists to identify the main purpose of their visit to the region (Fig. 2). They visit it because of its beautiful country and nature $(84 \%)$, family or friends living here $(47 \%)$, and monuments (42\%). A visit to see monuments is the second preferred reason of tourist travel to the region. The fifth reason is visiting its museums

According to the statistical data of the Slovak Statistical Office, since 2008 there has been a decreasing trend in overnight stays of tourists in the Banská Bystrica region. In 2012, nine districts reported a decline, and merely five, an increase in the number of such stays. Only three of the districts are listed here. 


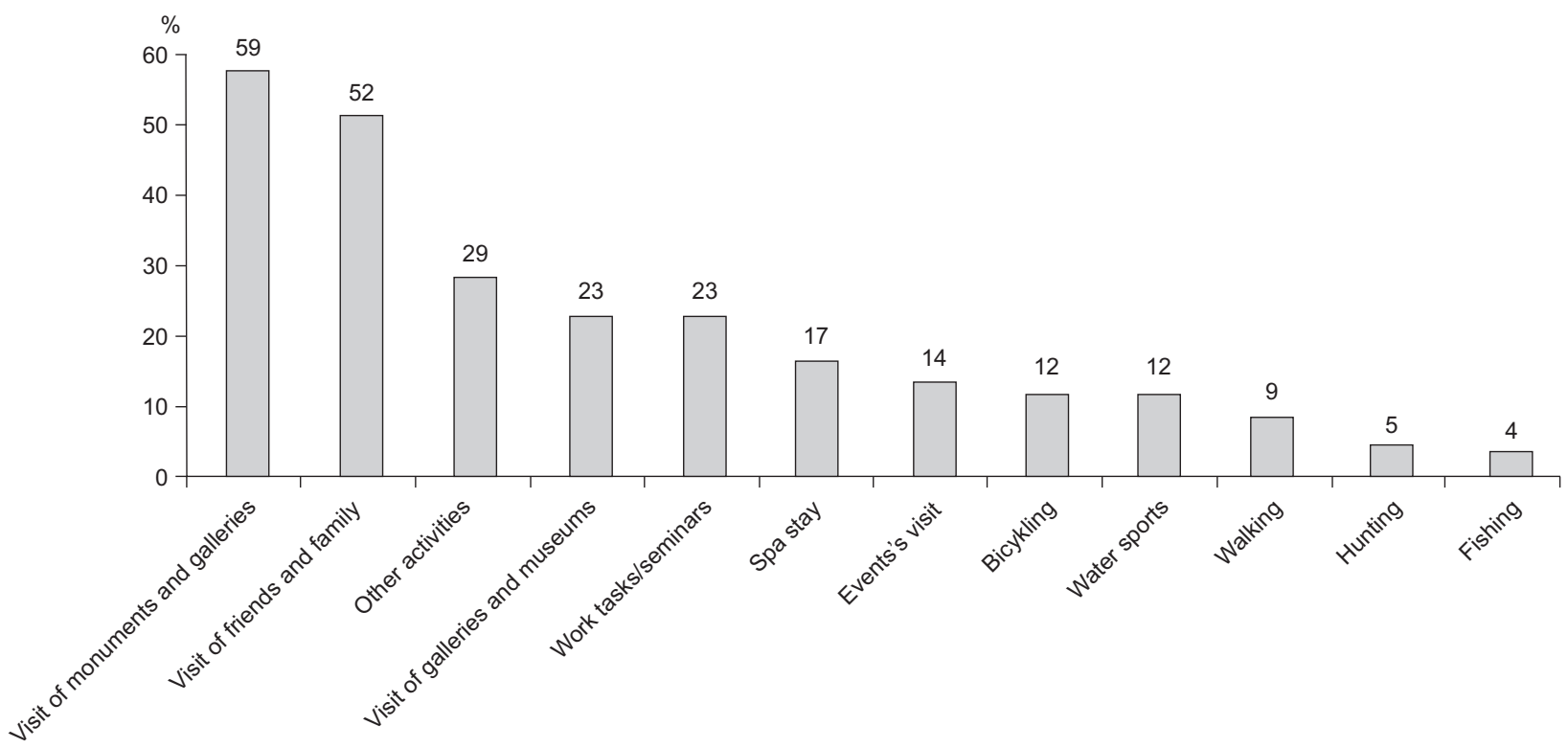

Fig. 3. Activities during a tourist visit in the Banská Bystrica Region. Source: own research.

and galleries, which is also closely connected with its heritage. To verify the respondents' answers to the question, we asked which activities they performed during their stay in the region (Fig. 3).

Fig. 3 confirmed the previous results (Fig. 2). Most visitors (59\%) went to monuments and historical places and 23\% visited museums and galleries. As the two graphs show, the main research has confirmed the cultural and historical heritage as an important factor of Slovak tourist visits. Therefore, we assume there to be a similar pattern of visits by foreign tourists.

Visually, these three towns have seen a remarkable improvement in their overall aesthetics, and with it, some level of population stability, except for Banská Štiavnica (Table 3). Because of its relative isolation from main highways, Banská Štiavnica will need to rely more heavily on its historical heritage for survival, instead of standard industrial activities. We see its demographic stability as dependent on the success of its cultural/ artistic endeavours, and its decline will diminish in the future (as reflected by a higher rate of tourist interest evident in an increase in overnight stays in hotels).
These three cities are among the more precious jewels of the region with a higher concentration of desired objects, and as such, they have been able to find enough interest for the restoration, rebuilding, and repurposing of these objects. It can be said that a region will prosper when the revitalisation of its official public heritage sites is also matched by the revitalisation of non-official ones. We claim that lessons learned from these sites can be replicated at a smaller scale in places that have lower concentrations of heritage objects if conditions for investment are improved.

\section{Recommendations for the facilitation of the creative and cultural industries towards rural redevelopment}

\section{Information deficit and ambiguity of responsibility}

This paper contends that it is self-evident that objects of interest exist in abundance throughout not only Banská Bystrica but also all rural regions

Table 3. Population in the research districts.

\begin{tabular}{|l|c|c|c|c|}
\hline \multicolumn{1}{|c|}{ District } & 2005 & 2008 & 2010 & 2012 \\
\hline Banská Bystrica & 111,186 & 110,908 & 111,029 & 111,148 \\
\hline Banská Štiavnica & 16,937 & 16,731 & 16,638 & 16,509 \\
\hline Ziar nad Hronom & 47,836 & 47,658 & 47,424 & 48,054 \\
\hline
\end{tabular}


in Slovakia. A simple drive through the country with its many towns and villages will illustrate a vast number of objects of historical significance. Many of these objects are in a state of perpetual purgatory, neither being removed nor renewed. It is as if the objects themselves were embarrassing reminders of the society's failures and as such they are ignored. Consider the following narrative:

Due to a decline in population and use, a decision is made to abandon a village train station. The station has the unique style reminiscent of the first Czechoslovak Republic. The shared ownership of the station between the state rail company and the town means that no one feels that it is their responsibility or obligation to arrest the object's decline, or at least to provide it with a minimum of safeguards. The abandoned property falls into further decay as vandals, thieves and the weather take their toll. The property, once a life-blood of the community, is now a disease with a visible reminder of everything that is wrong locally. Young people see this and move away; older people wait to die.

The above train station could also be seen as an opportunity for a potential investor to meet Maslow's higher hierarchical needs (esteem, self-actualisation). In some large-scale projects involving high-profile objects, this already occurs in Slovakia with renovations of manor houses and castles (Slovenska Lupča, Viglaš, Hronsek, Halič are just a few examples). These projects are very expensive and rather exclusive, and only available to individuals of significant wealth.

In keeping with the theme of this article, properties of historic significance can be referred to as icons of nostalgia (henceforth referred to as IONs). Many existing IONs are smaller than castles and places of royalty and offer a wide range of creative possibilities in many different categories. With a continuation of the above narrative, an opportunity for the train station becomes evident:

The weekly journey through the heartland takes me through several small towns that have seen better days. At one point in my journey, the railroad tracks follow the same route as the highway. In one such town there is a very lovely train station handsomely built as befits the symbol of prosperity and vibrancy that this town once had. It is easy to imagine a time when the station was full of people, and the proud stationmaster kept the place running like clockwork. In the age of steam, the railroad was king. Today, passenger trains are gone, but this lovely building remains, neglected, but still as beautiful as ever. It could be a nice project later in life and an opportunity to own something very unique.

The visual stimulus of the ION moves us towards nostalgic sentimentalism. According to investment theories, creativity requires a confluence of six distinct but interrelated resources: intellectual abilities, knowledge, styles of thinking, personality, motivation, and a supportive environment (Sternberg 2006). The creative individual provides the first four resources, the ION provides the motivation, and the local government provides the supportive environment. Government support can be found in the intangible assets of the public sector by data (geographical/ statistical data), audio-visual materials (active marketing) and documents produced or held by government agencies as part of their public service duties, specifically documentation (deeds, land registry, loans, etc.) (Borseková et al. 2014).

This brings up the complicated issues of ownership, privacy, and communal responsibility regarding information about an ION. The ambiguity of responsibility is at the core of an extreme deficit of adequate information. The upheaval of the Second World War and the following confiscation of land under socialism have led to uncertainty with concepts of proper ownership. This raises questions regarding IONs, especially those that are currently in abandon:

1. Who is the agent or individual that is the current owner of an ION?

2. If the object is in a state of neglect, what is the reason?

3. What should be the obligation of the ownership of objects, especially of an ION?

4. If these objects were available to an interested investor, what would be the cost?

It is felt that the communal good dictates that information pertaining to the above questions could be addressed by both government and non-governmental agencies. This signals the necessity to try and initiate action on an ION, and even to apply pressure on the current owners/ stakeholders to remove the property from its neglected state.

\section{Knightian uncertainty and transaction cost}

The Lucas paradox states that capital tends to flow from one developed area to another rather 
than to undeveloped regions even though labour and land rent may be cheaper there. This is evident in Slovakia, where capital flows to already economically stable areas and not to unstable ones. For reconsideration of the former, land rent must become irresistibly cheaper in the latter. This price has to be calculated in terms of both monetary cost and transaction cost.

Humans abhor unquantifiable risk, and attempts to invest in a rural area bring with them a lot of uncertainty. To steer interest to an ION, the problem of the deficiency of information must be addressed. This lack of information leads to Knightian uncertainty. People in general and within limits wish to behave economically, to make their activities and their organisation 'efficient' rather than wasteful. This fact is reflected in social policy assumed to be directed towards economic efficiency and reduced waste (Knight 1941). The Ellsberg paradox states that people tend to avoid uncertainty and the unknown in favour of quantifiable probability (Geweke 1992).

In rural regions, the conditions of an area are known and so are its future possibilities. When making an investment or when taking advantage of opportunities, the known 'unknowns' can also be calculated. However, the ambiguities of the available opportunities have so many 'unknowns' that decisions are avoided. With this inability to assess unknown information, no decisions are made at all.

Rules of economic action are governed by both, implicit rules (such as regulations and taxes) and social norms (such as negotiations and human interaction). This implies that there is a cost to any economic action that is above and beyond the action itself - the transaction cost of market participation. These transaction costs include time, taxes, regulations, and social interaction with the various stakeholders of a community (time being the most important factor).

All economic decisions have to develop enough rapidly occurring energy in order to overcome inertia and prevent decision fatigue - the notion that long periods of decision-making could lead to depleted mental resources and abandonment of effort. This is especially important during the early contemplation stage. Under normal economic conditions, standard institutional constructs reduce uncertainty in a decision. Even if all elements were calculable, it is still unknown what the future of an area will be since it is dependent on other actors in the market. The following is a typical example of decision uncertainties for an ION. A significant ION has been identified and there is a desire to invest in it.

1. The identification of the present owner may prove futile, exposing multiple claims on the property.

2. Various liens on the property have to be arbitrated, especially if the property was collateralised by past owner(s).

3. The new investor has to ascertain his/her acceptance as a new member in good standing in the community.

4. The cost of repurposing has to be assessed and any hidden costs must be uncovered.

5. The possibility of a future collapse of a town has to be calculated as the area continues to lose population.

6. Future demographics have to be calculated as the age bracket and socio-economic make-up of the town changes. In East Slovakia, a high Romany presence has become a factor in the decision.

With risky opportunities such as investments in an ION, the ease of a market transaction is important. The new rules meant to ensure high legal compliance with safety rules, historical preservation, impact on the environment, plus a lot of old rules left over from the days of socialism make the transactional costs of action too extreme. The need to lower these costs in terms of expenses and time has become a necessity and suggests some sort of a clearinghouse by a government agent or governmental ombudsman. This government agent would intervene when rules become more of an exercise in rent-seeking rather than societal or individual protection.

\section{Conclusions}

This paper has stressed the importance of nostalgic sentiment as both a social and an economic need. Icons of nostalgia are in short supply in urban centres but can be found in abundance in rural regions. This is especially true for Slovakia as it has a high concentration of historical and cultural icons that can feed this need for nostalgic sentiment. Since many of those elements are in a state of disrepair and quasi-ownership, they 
present a unique opportunity for creative and cultural industries. The study of the three historic mining centres of Banská Bystrica, Banská Štiavnica and Kremnica demonstrated a synergetic effect of a successful repurposing of historic, cultural and nostalgic icons. This was possible because of a high concentration of historical elements in those towns.

It is our contention that the success of these towns can be replicated throughout the country, but more must be done by both the government and quasi-government agents in providing information about these special icons. There is a distinct lack of information as to the ownership, regulations, and permissibility of the reconstruction and repurposing of icons of nostalgia. In this respect, it is felt that the transaction cost of redevelopment is too high and the uncertainties too unidentifiable, which leads to decision fatigue and the abandonment of effort. Without a more concerted effort to identify and save these elements of the cultural and historical heritage, many will reach a point of no return and be lost forever.

\section{References}

Appignanesi R., Sardar Z., Curry P., 1995. Post-modernism for beginners. Icon Books, Cambridge.

Batcho K., 2013. Nostalgia: Retreat or support in difficult times? The American Journal of Psychology 126(3): 355-367.

Borseková K., Petríková K., Primož P., 2014. Creativity and intangibles in the public sector: Sources and socio-economic importance. Mednarodna revija za javno upravo. Fakulteta za upravo, Ljubljana: 103-120.

Borseková K., Petríková K., Vaňová A., 2012. The methodology of use and building competitive advantage on the regional level. Journal of Security and Sustainability Issues 2(1): 41-50.

Borseková K., Vaňová A., 2011. Competitive advantage of Slovak Republic. International Journal of Multidisciplinary Thought 1(4): 237-257.

Boym S., 2002. The future of nostalgia. Basic Books, New York: 19-22.

Cole D., Mazureková M., 2014. Creating favourable conditions for tourism development in Slovakia. Univerzita Mateja Bela v Banskej Bystrici, Banská Bystrica: 79-88.

Geweke J. (ed.), 1992. Decision making under risk and uncertainty: New models and empirical findings. Kluwer Academic Publishers, Dordrecht, Netherlands.

Giddens A., 1990. The consequences of modernity. Polity Press, Cambridge.
Knight F., 1941. Review of Melville J. Herskovits' 'economic anthropology'. Journal of Political Economy 49: 247-258.

Kitson M., Martin R., Tyler P., 2004. Regional competitiveness: An elusive yet key concept? Regional Studies 38(9): 991-999.

Martin R., 2002. A study on the factors of regional competitiveness. 184 p. Online: http:// ec.europa.eu/ regional_ policy/ sources/ docgener/ studies/ pdf/ 3cr/ competitiveness.pdf (accessed 20 Feb. 2015).

Martin R., 2005. Thinking about regional competitiveness: Critical issues. East Midlands Development Agency, Nottingham, UK.

Pompurová K., 2011. Teoretické prístupy ku skúmaniu ciel'ového miesta cestovného ruchu. Ekonomická revue cestooného ruchu 45(3): 135-150.

Poussin G., Schischlik A., 2005. Cultural industries. Bureau of Publications, http:// www.unesco.org/ bpi/ pdf/ memobpi25_culturalindustries_en.pdf (accessed 27 Feb. 2015).

Power D., 2011. Priority sector report: Creative and cultural industries. European Cluster Observatory, Enterprise and Industry, European Commission.

Routledge C., Arndt J., Wildschut T., Sedikides C., Hart C., 2011. The past makes the present meaningful: Nostalgia as an existential resource. Journal of Personality and Social Psychology 101(3): 638-652.

Routledge C., Wildschut T., Sedikides C., Juhl J., Arndt J., 2012. The power of the past: Nostalgia as a meaning-making resource. Memory 20(5): 452-460.

Scott J., 1998. Seeing like a state: How certain schemes to improve the human condition have failed. Yale University Press, New Haven.

Solomon R.M., Marshall G.W., Stuart E.W., 2006. Marketing: Real people, real choices. Computer Press, Brno.

Söndermann M., Backes Ch., Arndt O., Brünink D., 2009. Culture and creative industries in Germany: Defining the common characteristics of the heterogeneous core branches of the "cultural industries" from macro-economic perspective. Bundesministerium für Wirtschaft und Technologie, Cologne, Bremen, Berlin.

Sternberg R.G., 2006. The nature of creativity. Creativity Research Journal 18(1): 87-98.

UNESCO, 2003. Convention for the Safeguarding of the Intangible Cultural Heritage. http:/ / www.unesco.org/ culture/ ich/ index.php?pg=00006 (accessed 4 April 2014).

UNESCO, 2005. Convention on the Protection and Promotion of the Diversity of Cultural Expressions. http:/ / unesdoc.unesco.org/ images/ 0014/ 001429/ 142919e.pdf.

Vaňová A., Petríková K., Borseková K., 2010. Marketing places as a tool of territorial development and its application in region Liptov. National School of Political Studies and Public Administration, Bucharest: 1-10.

Vess M., Arndt J., Routledge C., Sedikides C., Wildschut T., 2012. Nostalgia as a resource for the self. Self and Identity 11(3): 273-284.

Zhou X., Sedikides C., Wildschut T., Gau D., 2008. Counteracting loneliness: On the restorative function of nostalgia. Psychological Science 19(10): 1023-1029. 